\title{
Pros and cons of the PRM system (National Medical Emergency Service), from the viewpoint of paramedics
}

\author{
Krzysztof Samoliński, Adam Fronczak
}

Department of Public Health, Medical University of Warsaw, Poland

\begin{abstract}
The amended Regulation of the $8^{\text {th }}$ September 2006 concerning the National Medical Emergency Service in Poland governs how this system operates. Its functioning in a medical emergency situation is currently based on a combination of the Anglo-American model with the Franco-German one, where physicians are absent in the former, within an arriving emergency medical team, but are present in the latter. The Polish system has two categories of emergency medical teams: basic (consisting of paramedics and system nurses) and specialist (which additionally includes a system doctor).

The presented study is based on all the available literature sources on emergency medicine. It describes in summary form all the most commonly found problems facing the system of emergency medicine in Poland which can adversely affect its operation. These consist of the following: 1 . There is no unified education system. 2. Regional differences abound in the numbers of hospital emergency departments and composition of emergency medical teams throughout Poland. 3. The limited availability and high prices of professional training. 4. A lack of psychological counselling for medical staff. 5. An inefficient emergency callout system; a patient calls 112 and connects to the Emergency Notification Centre and is then forwarded on to an emergency medical service dispatcher, thus increasing delays in providing assistance. Study conclusions: The following requirements were identified: 1 . Standardising the education system for emergency medical services in Poland. 2. Adopting standardised methods for setting up emergency medical teams and hospital emergency departments. 3. Providing psychological care for medical/paramedical staff. 4. Improving the medical emergency service notification/calling system.
\end{abstract}

KEY WORDS: National Medical Emergency Service, PRM system, medical emergency team, hospital emergency departments (SOR).

ADDRESS FOR CORRESPONDENCE: Krzysztof Samoliński, Department of Public Health, Medical University of Warsaw, 61 Żwirki i Wigury Street, 02-091 Warsaw, e-mail: krzys.samolinski@gmail.com

\section{INTRODUCTION}

There are two predominant systems of emergency medical service in European countries: the Anglo-American and Franco-German models. The latter does not recognise emergency medicine to be a separate medical specialisation. Its operation is not based on paramedics but on appropriately qualified physicians in specialisations such as anaesthesiology, surgery or internal medicine who are supported by paramedics or paramedically trained nurses (system nurses). In a situation judged to be life-threatening, the scene-arriving paramedic sum- mons a physician tasked with starting patient treatment, there being at this moment no option for taking the patient to hospital. This principle is often termed 'Stay and Stabilise' or alternatively 'Delay and Treat'. Only when the patient's condition has stabilised or a diagnosis has been made is an ambulance summoned, which includes a system nurse and one or two paramedics. Because there is no hospital emergency department in this system, the patient is admitted to the appropriate hospital department as designated by the attending physician for further treatment. The Anglo-American 
system is based on the principles of 'Scoop and Run' and 'Load and Go'. The medical emergency team consists only of paramedics whose tasks are to stabilise vital body functions and to bring the patient as quickly as possible to hospital emergency departments, where a physician specialising in emergency medicine then administers the appropriate treatment [1-4].

In Poland, the national system for medical emergency services is a combination of these two aforementioned models. According to the typical Anglo-American model, there is no doctor present within an emergency medical service team, where the 'Load and Go' principle ensures that the patient's body functions are stabilised at the place of the accident/incident. The patient is then transferred to a hospital emergency department. In the Franco-German system, the first to arrive are an ambulance team that includes a doctor who, in accordance with the 'Stay and Stabilise' principle, makes an initial diagnosis and first treats the patient in situ. On the basis of a preliminary diagnosis, the patient is then transported to the relevant hospital department, without the need of any hospital emergency departments, being anyway absent in this system.

Poland endeavours to introduce a typical AngloAmerican system through reducing the number of specialist teams. At present, emergency medical teams are divided into two types: basic (made up of drivers or paramedic-drivers, paramedics and/or system nurses), and specialist (which additionally includes a system doctor). For the Aviation Emergency Service, such a team obviously also includes a pilot. Depending on the patient's condition, emergency medical procedures are either performed at the place of the incident (in accordance with the 'stay and stabilise' principle) or, in life-threatening cases, the patient's vital body functions are stabilised, after which the patient is rapidly transported to a hospital emergency department, i.e. according to the 'Load and Go' principle.

\section{HOW THE POLISH NATIONAL MEDICAL EMERGENCY SERVICES ARE ORGANISED}

Up to the present day in Poland, there is however no unified system determining how an emergency medical team is assembled. The make-up of such teams still varies according to region. For example, there are three team members operational in the Warsaw region, but only two in Piaseczno (a neighbouring southern region), which includes a driver $[1,2]$. Such a situation is problematic. Introducing a unified system in Poland has its supporters, whilst equally there are those who take the opposing view and argue that regional differences/circumstances dictate different requirements. Solutions to this issue/controversy are currently being debated.

An important part of the above-described models is in having unified standards for paramedics. For the Franco-German system, paramedics or system nurses are those suitably qualified after completing the relevant training courses and a period of internship. In contrast, paramedics from the Anglo-American system are medical school graduates of emergency medicine. In both cases, the passing of an official state examination is necessary for the right to practise this profession. This guarantees that, despite any differences in teaching programmes between individual schools, the duties of a paramedic are carried out by those with the same level of skills and knowledge [1-4].

Until 2013 paramedics had also been trained by a biannual post-high school system. From 2013 onwards, after passing the relevant examinations, diplomas in Poland were awarded by a specially appointed college/university commission that includes selected lecturers from any given university. A paramedical staff is thus created with diverse levels of both knowledge and practical skills according to the different requirements and levels set by individual college centres, which take account of and recognise any post-high school and matriculation education obtained from before 2013, as well as BSc qualifications (Bachelor of Science) awarded in emergency medical services. Such a diversified education system raises doubts, especially that on the one hand there are academic centres with a medical profile whilst there are also other teaching institutions that are not necessarily medical ones. Teaching staff are diversely qualified, as is the access to teaching workshops, which includes having practical access to the appropriate health care facilities and being taught in pre-clinical subjects. So, is the quality of education for paramedics at such different places comparable? This issue thus needs to be investigated and analysed. It is therefore advisable to consider introducing a joint state examination to iron out these differences using the following means: 1) Forcing through an obligatory teaching programme and qualifying examination, 2) Establishing limiting conditions in order to verify whether candidates are professionally capable of working in the PRM system.

The Supreme Audit Office (NIK in Polish) positively assessed the paramedic education system according to the needs of the PRM system, yet public administration bodies were adversely assessed on paramedic staffing requirements [5]. Reports prepared by national and voivodship (provincial) consultants on emergency medical services proved unhelpful because the numbers of healthcare professionals required for particular population groups had not been defined. Furthermore, there was insufficient collaboration for creating education policy in the medical professions between the Ministry of Science and Higher Education (supervising higher education institutions, including vocational schools), with the Ministry of Health (supervising medical schools) [5]. This has been confirmed by surveys, where $43 \%$ of paramedic subjects stated that during their education more time should have been devoted to patient-based training [6], and thus this needs to be increased. 
The quality of medical health service delivery is inherently linked to post-graduate education. Mandatory regulations set out the working requirements for paramedics. The teaching and training courses so devised are based on these regulations, which guarantee maintaining high levels of knowledge and practical skills to paramedics in the national system for delivering medical emergency services, who are statutorily obliged to undergo further training in emergency medicine. It should however be noted that surveys show that $78 \%$ of paramedics and $60 \%$ of system nurses report having a problem with the availability of training courses for the furthering of their professional qualifications [6, 7]. New programmes have thus now arisen to resolve this issue of availability which are financed by the European Union (EU).

The mental state of paramedics is an important issue concerning the health services so provided to the public, where stress and problems in communicating with patients and other healthcare providers are additional areas for psychologists to consider. It is the psychologists' task to assess the mental state of paramedics and whether they are able to cope with work-related stress and continue on with their professional duties; this could include analyses of detailed interviews so conducted. Outcomes of such surveys show that $60 \%$ of paramedics struggle with work-related stress and 56\% complain about the stressful nature of dealing with administrators at their workplace [8]. Detailed studies have demonstrated that surveyed paramedics are subjected to verbal aggression from their superiors. In addition there are also other stress factors [9].

Paramedics work in an environment with sick people who need help and who can often behave irrationally - threatening paramedics, being aggressive and being insulting to other staff. There are alarming statistics for such occurrences. Up to $60 \%$ of those surveyed said that they had encountered threats of physical assault on their persons, whilst $32 \%$ said that this had actually taken place $[10,11]$. Such incidents adversely affect the ability to further perform their duties. A person under stress is more liable to make errors in delivering health services. Psychological care would thus appear to be a vital support to paramedics, so they should have unlimited access to a psychologist, and also their mental state should be periodically monitored.

Among the organisations involved in the national system for delivering emergency medical services, a significant role is played by the Emergency Call Centre (in Polish CPR). At present its operation still lies outside the theoretical principles set out in the legislation. The September 2012 report by the Supreme Audit Office states that no emergency call centres were set up between 2006 and 2012 that fulfil the legislative requirements of STARE; nor indeed have there been any up till now (2018) [12]. It must however be said that creating a uniform emergency call centre system is a long-lasting process. It would now be nearing completion were it not for delays caused by political interference. To function properly such a system must be reliable, otherwise any errors occurring may jeopardise the patient's health and life. CPRs started to be introduced after the legislative Act of $22^{\text {nd }}$ November 2013 regarding medical emergency call-outs/notifications. Up till then, the emergency 112 number was still not functioning correctly [13]. It should be stressed that since 2006 there have been three major conceptual changes to the system aimed at optimising its operation.

In 2014 , the ministry responsible for administration and digitisation as well as the Ministry of Health issued a number of ordinances describing the following: the operating principles of CPRs, requirements to be met by emergency call centre operators (with appropriate standards incorporated into their training) and operating rules established for taking emergency calls [14-16]. The first Law on National Emergency Medical Services was enacted in 2001, whilst the current system functions according to legislation on National Emergency Medical Services from 2006. The aforementioned provisions were prepared based on experience gained during the 6 years that the medical emergency system functioned, which as a result ensured a high probability of reliable performance. Currently, the Emergency Call Centre systems and the ambulance dispatching system still operate independently. To directly call for an ambulance, 999 can be dialled or the emergency 112 number. Making a 112 call however significantly extends the time required for help to arrive, because the CPR dispatcher has anyway to connect to the 999 number after receiving emergency incident information from a caller and then either relays the information or directly switches through the caller.

The previously cited NIK report from 2012 stated that $80 \%$ of cases reported to SOR (hospital emergency departments) were patients in non-life-threatening situations. Another study from the same year found that $22 \%$ of emergency callouts were unjustified in the Lublin and Grabow areas $[12,17]$. This constitutes a significant burden to the National Medical Emergency Services. It is important that public awareness is raised on the role and operating principles of such emergency services. Special attention should be given to reporting those adverse symptoms that pose a serious threat to a patient's health or life which justify summoning the medical emergency team (ZRM in Polish).

Introducing legal liabilities for the improper/unjustified use of emergency medical teams and hospital emergency departments could improve such a situation. This is however an issue fraught with difficulty, because it concerns a patient's right to health care, and is also related to their awareness and knowledge about health safety. Nonetheless, in order for the system to successfully function, patients should be given easier access to general practitioners (GPs) as well as to medical services 
during night-time and festive days. It is impossible to legally penalise a patient who has difficulties in accessing a primary care physician. An in-depth analysis on how these institutions operate should reduce the possibility that home visits are refused to patients whose health prevents them from attending their doctor's surgery (i.e. GP's clinic) [18]. Taking such measures should thus limit sending emergency medical assistance units to those who are not faced with sudden life-threatening conditions/situations.

The notion encompassed within the Minister of Health regulations from 3.11.2011 regarding the hospital emergency departments on 'the number of personnel necessary to secure and operate a given ward' allows great scope for the administrative bodies of hospitals to introduce staff changes. Whenever needs are initially underestimated in hospital units, there is a risk of inefficiency that may result in longer hospital stays and longer patient queues for awaiting medical care. Current analyses indicate that SOR performance is enhanced by employing more staff. There is no provision under Polish law that regulates the exact number of SOR staff deployed, thanks to which human resources can be allocated depending on the needs for any given region. In order to improve the quality of health services, it is necessary that hospital emergency departments be reorganised.

The professional duties of a paramedic are limited to: providing emergency aid to persons under a sudden health threat risk and monitoring the patient's health as well as providing medical care during their transport. The system nurse also has a number of other services that they can provide concerning rehabilitation, treatment, diagnosis and prevention, thereby extending the range of possibilities for aiding the patient. One should therefore consider whether paramedics should be assigned to such areas as medical segregation, patient registration and admission, resuscitation and treatment along with providing any initial intensive care.

In addition to the medical staff at a hospital emergency department, both paramedics and system nurses should be deployed. They should however be assigned to the relevant areas as defined in the regulations [19].

\section{CONCLUSIONS}

The following are recommended for improving the state of the medical emergency system:

1. Standardising the education system for emergency medical services in Poland.

2. Adopting standardised methods for setting up emergency medical teams and hospital emergency departments.

3. Making teaching courses and training more easily available to paramedics and system nurses.

4. Providing psychological care for medical/paramedical staff.

5. Improving the medical emergency service notification/calling system.
In order to improve the efficiency of the ambulance service and hospital emergency departments, the inflow of patients entering these components of the medical emergency system should be reduced. It is therefore necessary that an informational campaign be launched to raise patient awareness for the justification in calling for an ambulance and in making emergency hospital visits. A better definition of the rules is required for making GP visits (primary medical care) or in seeking medical assistance during the night-time or on festive days. This will help unburden the system. It should be recognised that improving the organisation of the medical emergency healthcare system requires many years of effort and hard work, due to its complex nature. Despite visible progress made in improving the health care system, many years are still necessary for it to be fully functional and fully integrated with other parts of the healthcare system, as statutorily designated to provide such assistance to the civilian population.

\section{DISCLOSURE}

The authors report no conflict of interest.

\section{References}

1. Biuro analiz i dokumentacji. Organizacja służb ratownictwa medycznego w wybranych państwach. Opracowania Tematyczne, sierpień 2013 r. [Analysis and documentation office. Organization of emergency medical services in selected countries . Thematic Studies, August 2013.] Available from: https://www. senat.gov.pl/gfx/senat/pl/senatopracowania/53/plik/ot-622.pdf (accessed: 14 May 2018).

2. Kosydar-Bochenek J, Ozga D, Szymańska J, Lewandowski B. Systemy ratownictwa medycznego na świecie a system polski [Emergency Medical Service (EMS) systems on the world and the Polish system]. Zdrowie Publiczne 2012; 122: 70-74.

3. Sultan Al-Shaqsi. Models of International Emergency Medical Service (EMS) Systems. Oman Medical Journal 2010; 25: 320-323.

4. Page C, Sabat M, Vazquez K, Deniz Yalcin Z. Analysis of Emergency Medical Systems Across the World. Worcester Polytechnic Institute, Project Number: MQP-IQP 2809, Mirad Laboratory, April 25, 2013. Available from: https://docplayer. net/1321251-Analysis-of-emergency-medical-systems-acrossthe-world.html (accessed: 14 May 2018).

5. Raport Najwyższej Izby Kontroli z czerwca 2010 r. Informacja o wynikach kontroli systemu kształcenia oraz przygotowania do zawodów pielęgniarki, położnej i ratownika medycznego [Report of the Supreme Audit Office of June 2010. Information on the results of the inspection of the education system and preparation for the occupations of a nurse, midwife and paramedic]. Available from: https://www.nik.gov.pl/plik/ id,1864,vp,2228.pdf (accessed: 14 May 2018).

6. Frydrysiak K, Grześkowiak M, Pytliński A. Wzajemne relacje ratowników medycznych i pielęgniarek systemu w zakresie swoich uprawnień [Interrelations concerning the competences between paramedics and nurses of the emergency system]. Nowiny Lekarskie 2009; 78: 23-29. 
7. Tomaszewska M, Cieśla D, Czerniak J, Dykowska G. Możliwości doskonalenia zawodowego pielęgniarek - potrzeby a rzeczywistość [Possibilities of professional nursing improvement - needs and reality]. Problemy Pielęgniarstwa 2008; 16: 40-47.

8. Binczycka-Anholcer M, Lepiesza P. Stres na stanowisku pracy ratownika medycznego [Stress at the workplace of medical rescuer]. Hygeia Public Health 2011; 46: 455-461.

9. Kowalczuk K, Krajewska-Kułak E, Klimaszewska K, Kondzior D. Wpływ obciążenia psychicznego pracowników zintegrowanego zespołu medycznego na zadowolenie $\mathrm{z}$ wykonywanej pracy [The effects of stress on workers of emergency team and job satisfaction]. Problemy Pielęgniarstwa 2009; 17: 315-320.

10. Kowalczuk K, Jankowiak B, Krajewska-Kułak E i wsp. Ocena stopnia narażenia ratowników medycznych na agresję w miejscu pracy [Assessment of the exposure of paramedics to aggression in the workplace]. Roczniki Pomorskiej Akademii Medycznej w Szczecinie 2009; 55: 76-80.

11. Fedorczuk W, Pawlas K. Ryzyko zawodowe w pracy ratownika medycznego [Occupational risk factors of a medical rescue worker]. Hygeia Public Health 2011; 46: 437-441.

12. Raport Najwyższej Izby Kontroli z września 2012 r. Funkcjonowanie systemu ratownictwa medycznego [Report of the Supreme Audit Office of September 2012. Operation of the medical emergency system]. Available from: https://www.nik.gov.pl/ plik/id,4333,vp,6192.pdf (accessed: 14 May 2018).

13. Raport Najwyższej Izby Kontroli z lipca 2010 r. Informacja o wynikach kontroli funkcjonowania numeru alarmowego 112 na terenie Polski [Report of the Supreme Audit Institution of July 2010 Information on the results of the control of the 112 emergency number functioning in Poland]. Available from: https:// www.nik.gov.pl/plik/id,1903,vp,2300.pdf (accessed: 14 May 2018).

14. Rozporządzenie Ministra Zdrowia z dnia 10.01.2014 r. w sprawie ramowych procedur przyjmowania wezwań przez dyspozytora medycznego [Regulation of the Minister of Health of $10 / 01 / 2014$ on the framework procedures for accepting calls by a medical dispatcher]. Available from: http://prawo.sejm.gov.pl/ isap.nsf/download.xsp/WDU20140000066/O/D20140066.pdf (accessed: 14 May 2018).

15. Rozporządzenie Ministra Administracji i Cyfryzacji 29.07.2014 r. w sprawie numerów telefonicznych, które mogą być obsługiwane $\mathrm{w}$ ramach systemu powiadamiania ratunkowego [Regulation of the Minister of Administration and Digitization on July 29, 2014 regarding telephone numbers that may be handled as part of the emergency notification system]. Available from: http:// prawo.sejm.gov.pl/isap.nsf/donload.xsp/WDU20140000574/O/ D20140574.pdf (accessed: 14 May 2018).

16. Rozporządzenie Ministra Administracji i Cyfryzacji z dnia 21.02.2014 r. w sprawie szkoleń operatorów numerów alarmowych [Regulation of the Minister of Administration and Digitization of 21/02/2014 regarding the training of operators of emergency numbers]. Available from: http://prawo.sejm.gov.pl/ isap.nsf/download.xsp/WDU20140000269/O/D20140269.pdf (accessed: 14 May 2018).

17. Aftyka A. Ocena funkcjonowania zespołów ratownictwa medycznego w Polsce. Rozprawa na stopień doktora nauk medycznych [Assessment of the functioning of medical rescue teams in
Poland. Dissertation for the degree of doctor of medical sciences]. Zakład Pielęgniarstwa Anestezjologicznego i Intensywnej Opieki Medycznej, Lublin 2012.

18. Michalak G. Gdy liczą się sekundy? [When seconds count?]. Miesięcznik Puls, maj 2013 r.

19. Rozporządzenie Ministra Zdrowia z dnia 3.11.2011 r. w sprawie szpitalnego oddziału ratunkowego [Regulation of the Minister of Health of 3.11.2011 regarding the hospital emergency department]. Available from: http://prawo.sejm.gov.pl/isap.nsf/ donload.xsp/WDU20112371420/O/D20111420.pdf (accessed: 14 May 2018)

\section{AUTHOR'S CONTRIBUTIONS}

KS, AF prepared the research concept and collected data of the publication. All authors analysed data, wrote the article and finally approved it. 